\title{
The Novel Changes in Pakistan's Party Politics: Analysis of Causes and Impacts
}

\author{
Xiang $\mathrm{Wu}^{1} \mathbb{D} \cdot$ Salman $\mathrm{Ali}^{1}$
}

Received: 21 October 2019 / Accepted: 18 July 2020 / Published online: 25 July 2020

(c) Fudan University 2020

\begin{abstract}
Transformation in a political system regarding number of parties is a significant phenomenon which creates ample grounds for scholarly discourse. The Pakistani political system witnessed a change in the party politics where it transformed from a two-party system to a three-party system in a relatively short time period. Pakistan Tehreek-e-Insaf emerged on the political scene and after just two elections was able to form a government. Challenging the status quo political forces through organizational mobilization, ideology, counter narrative, and redeeming civil military balance, PTI successfully achieved the systemic transformation in political structure of Pakistan. The change in a complex political fabric was attempted across various spectrums of party dynamics and electoral mechanics both at the federal and provincial legislatures employing diverse strategies. The challenge at hand is the translation of those mechanics of change into political realities and policy orientations while dealing with structural intricacies, domestic compulsions of economy, and external relations. China has less experience dealing with this change in the political system and this new important player in Pakistan's politics. PTI also lacks experience managing external relations which has implications for both the important stakeholders. Undergoing political transition dealing with resistance to change from political actors and managing external relations will define the future of political stability and its impact over China-Pakistan relations.
\end{abstract}

Keywords Pakistan · Party politics · Pakistan Tehreek-e-Insaf · Imran Khan · Organizational strength $\cdot$ China-Pakistan

Xiang Wu

wux17@fudan.edu.cn

Salman Ali

19110170050@fudan.edu.cn

1 School of International Relations and Public Affairs, Fudan University, Shanghai, China 
Table 1 PTI's electoral performance 1997-2018. Source: Network of Research in International Affairs. https://www.noria-research.com/app/uploads/2016/10/Noria-MUFTI-Pakistan-VE-PDF.pdf; The Economic Times. https://economictimes.indiatimes.com/news/international/world-news/imran-khans-pti-emergeslargest-party-with-116-seats-official-results/articleshow/65177307.cms?from=mdr

\begin{tabular}{llcc}
\hline Election year & No. of NA seats contested & Seat share in NA & $\begin{array}{c}\text { Vote share } \\
\text { in NA (\%) }\end{array}$ \\
\hline 1997 & 133 & 0 & 1.65 \\
2002 & 92 & 1 & 0.83 \\
2008 & Boycotted the election & & \\
2013 & 230 & 33 & 16.92 \\
2018 & 270 & 116 & 51.7 \\
\hline
\end{tabular}

\section{Introduction}

On July 28, 2018, former Pakistani cricketer Mr. Imran Khan led the Pakistani Tehreek-e-Insaf (PTI, Movement for Justice) to win a relatively large majority of seats in the National Assembly than the previous elections. Imran Khan was successfully elected as the 22nd Prime Minister of Pakistan by the National Assembly (NA) on August 17, 2018. The rapid rise of his party since has surprised political observers. In April 1996, a socio-political movement inspired by the slogan "justice, humanity, and self-reliance" led to the formation of PTI by Imran Khan. In 1997, a year later, PTI contested the election hailed as the "third force" in Pakistan's otherwise two-party system (Mufti 2015:2). In the general elections of 2002, PTI won just one NA seat. In the 2013 general election, it won 33 out of the 342 seats, making it the third largest party in the NA. Table 1 indicates the rapid growth of seats in NA and voters' support for PTI from its establishment to 2018.

In the 2018 general election, PTI won 116 of the contested seats, and the share of votes in the NA increased to $51.7 \%$. After several rounds of seat adjustments, PTI now holds 156 seats, making it the largest party in the NA (NAP 2019). Observers of Pakistani politics explained PTI's sudden rise as a combination of the following factors: "fortuitous timing," an effective narrative that resonated with a discontented citizenry and a charismatic leader who had finally "hit his stride" (Yusuf 2011; Rafiq 2012; Tahir 2012; Tupsy 2018). It has been 2 years, since the party obtained its ruling status. With this development, the political landscape of Pakistan's political parties has changed from the past. The literature produced on political development in Pakistan has different orientations according to the political evolution in the country. The primary focus has been the institutional rifts between civil and military through respective regimes and constitutional history. In addition, the political evolution is also overshadowed by the challenges of federalism, particularly ethno-linguistic strife in East Pakistan which finds reflection in much of the discourse produced on politics in Pakistan. The evolution of political parties in the nascent democracy of Pakistan was carried away by structural problems which influenced the literature as well. 
Saeed (1966) pointed out that there is a serious conflict between the political leaders and civil-military bureaucracies, which constitutes a structural constraint of Pakistan's political system leading to parochial political parties with limited horizons and goals. Jahan (1972: 141) argued that political power is highly localized and fragmented in Pakistan. Political parties, instead of building up their organizations or mass support, generally co-opt locally influential leaders with their own group of supporters. Hussain (1979: 145) identified that a military bureaucratic oligarchy has influenced the political fabric throughout the history of Pakistan, especially during its formative years. He investigated how military rulers have used political parties to extend their power. Ziring (1997) blamed the political leaders of different political parties for the weakness of the political system of Pakistan. In his view, mostly, the political forces have been focusing electioneering that would limit space for civil society and institutionalization of political party. Rizvi (2001) argued that due to lack of organizational capacity and integration, political parties could not strengthen their institutional strength, leaving space for the military in politics. The Punjab-based civil-military bureaucracy dominated the political fabric, leaving the other regions struggling, agitating, and marginalized. Hussain (2013) has given more attention to the political history than party politics and considers the military as the pivotal point in politics of Pakistan.

The literature on politics in Pakistan gives much attention to situational analysis and institutional imbalances, but there is very little emphasis on the transformation into a multi-party system. The article dwells on this fundamental change from a loosely structured two-party system into a multi-party system. When the PTI entered the Pakistani political scene, it adopted novel ways to achieve the status of a third major political force in the presence of the Pakistan Muslim League-Nawaz (PMLN) and Pakistan People's Party (PPP). Existing literature mainly focuses on Imran Khan's personal charisma (Zaidi 2018; Hadid 2018; Ghosh 2018) or the position of the political party at the federal level (Yousaf 2016; Rizwan et al. 2016; Behera 2018), but pays less attention to the ideology, organizational, and mobilizing capacity and standing at the local level. The article attempts to fill the gap in the literature about multi-party system in Pakistan. The first section describes the three characteristics of the novel changes observed in Pakistan's political party dynamics since the PTI won the election. The subsequent part explains why changes have occurred in the ideology and organizational mobilization ability of the PTI, as well as changes in civil-military relations. The final section looks at the impact that these novel changes may have on Pakistan's domestic politics. One of the significant aspects has been bringing people from the middle class into leadership positions. Another significant impact is also observed in the foreign policy picture which has not been affected by the political regimes previously, since it was previously controlled by the military (Ahmed 2010).

\section{The Novel Changes in Pakistan's Party Politics}

Pakistan's party politics has witnessed a new trend of third party which held strong political ground in the electoral mechanics of the country. It stepped into an orderly two-party rotation since 2008. The PPP and the PML-N have strong voter bases in 
the provinces of Sindh and Punjab, respectively. PTI developed its voter base in Khyber Pakhtunkhwa province, which was hit by terrorism and bad governance. Since PTI won the 2018 general elections and emerged as a strong party in NA, the party politics of Pakistan has undergone important changes at the federal and provincial levels. The changes correspond to both the political scenario and social structure devoid of upholding democratic traditions. The new changes have the following characteristics:

\subsection{Transformation from a Two-Party to a Three-Party System}

From 2008 to 2018, the parliamentary democracy in Pakistan has witnessed transition of two regimes peacefully completing their respective constitutional terms. The PPP and the PML-N served their terms and handed over power after elections, which was unprecedented in the political history of Pakistan (Chaudhary 2013; Shah 2013). During their respective periods in power, the two parties have made great progress on issues such as political stability, economic growth, diplomatic cooperation, and combating terrorism. The two-party structure in the political fabric had established itself particularly in the context of their previous respective terms in government. Public opinion had not only accepted the two-party structure, but also had expectations of long-term rotation. PTI's victory ended this pattern of two-party rotation.

The 2008 general election laid the basic pattern of party politics in Pakistan's democratic order. ${ }^{1}$ The election witnessed the PPP, led by Asif Ali Zardari, win 120 seats in NA, which made it the largest party in parliament (BBC 2008). Half a year after the election, General Pervaiz Musharraf handed over power to the elected government. The President, the Prime Minister, and the Speaker came from the PPP, which secured a majority in NA. For the first time since the founding of Pakistan, the ruling party held these key powers at the same time. During the 5-year term from 2008 to 2013, the People's Party utilized political stability and mobilized resources for governance, which achieved domestic political stability to a considerable extent, safeguarding the social order and preventing economic downturn. Although the PPP was replaced by the PML-N in the 2013 general election, it made history by becoming the first party ever to complete its 5-year term and introduced a landmark 18th constitutional amendment bringing about one of the most dramatic deconcentrations of power in Pakistan (Cookman 2010).

In the 2013 Pakistani general election, PML-N won the largest number seats in NA. To establish a government, independent candidates joined the PML-N which allowed that party to establish a simple-majority government (Tribune 2013). The

\footnotetext{
${ }^{1}$ Since Pakistan's founding in 1947, it has experienced four military regimes. In chronological order: Mohammad Ayub Khan (1958-1969), Agha Mohammad Yahya Khan (1969-1971), Muhammad Zia-ulHaq (1977-1988), and Pervez Musharraf (1999-2008).
} 
elections marked the first transition in the country from one democratically elected government to another (PRI 2013). In the general election of May 2013, PTI gained a rapid increase in seats in NA and in the four provincial assemblies, forming a government in the province of Khyber Pakhtunkhwa. Although the political status of PML-N was stable, the PTI emerged as the third largest party, wining almost as many seats as the PPP. After the 2018 general elections, the PTI, which had no previous experience on the federal level, won a relative majority in the parliament, breaking the expectation and sequence of the two parties' rotation.

\subsection{Change in Tradition of Dynastic Politics}

Political parties in Pakistan have always been dominated by influential families and their heads. For instance, the Bhutto family dominated the PPP and the Sharif family dominated the PML-N. The Bhutto family had huge land holdings and political influence in Sindh, while the Sharif's family belonged to the rich industrial class of Punjab province. The status quo political parties of Pakistan have oligarchical system, because they are identified by their founders instead of ideology or policy (Khan 2018a, b). For instance, there are core committees and central working committees those not only control the party politics but also give direction to the party (Aziz 1976: 209).

Since the founding of the country, Pakistan has inherited the institutional legacy of British India, allowing multiple political parties to gain ruling status through competitive elections. However, at the same time, Pakistan is also in the process of transition from a traditional agrarian country to a modern industrial country. The political parties and party systems that grew up along with the founding of Pakistan were all influenced by the traditional social structure, which means that the traditional factors such as family, social status and religion still perform a substantial role in Pakistani politics. The party politics of Pakistan is highly personalized. The political system struggles, because personalities and pressure groups are more powerful than the institutions and ideologies (Malik 2011: 43). Dynastic politics is just a new face of personalized politics, further deteriorating the parliamentary system (Khan 2018a, b).

Compared with the PPP and PML-N and their respective strong families, PTI founder Imran Khan was different: he was born in 1952 in a well-off nonpolitical family in Lahore (Khan 2011: 19). After the 2018 election, the PTI's rise to power at the federal level completely altered the strong dynastic political fabric in Pakistani politics where the PPP and PML-N are ruled by the third generation of their respective families.

The PPP is a typical political party dominated by a feudal family having strong influence in the traditional social structure founded in 1967; the PPP has had five leaders 
so far, all belonging to the same family. ${ }^{2}$ The leadership of the party remains with the family members of respective parties throughout the history. Zulfikar Ali Bhutto, founder of the People's Party, was born in the rich Bhutto family in the Larkara district of Sindh, Pakistan. The Bhutto family is the first generation of politicians from Sindh province, the second most important province after Punjab, who gained influence at the national level. Estimates vary as to the actual acreage owned by the Bhutto clan. Before the 1959 Land Reforms, each major clan head reportedly held around 40,000-60,000 acres of extremely productive land in Larkana, Jacobabad, Thatta, and Sukkur (Taseer 1979). PPP's ballot and popularity base are rooted in Sindh; it has confidence in Sindh's voters for securing electoral majority in National and provincial assembly.

Muhammad Nawaz Sharif, the former leader of PML-N, was born in the Sharif family in Punjab and his father was the founder of the Punjab province's steel and agriculture groups popularly known as Sharif group and Ittefaq foundries. Nawaz Sharif entered politics during the reign of General Zia-ul-Haq and was elected as chief minister of Punjab in 1985. He was re-elected after the end of the Martial Law under the Military Government in 1988. With deep political and business foundations in Punjab, Nawaz Sharif has served as Prime Minister of Pakistan from 1990 to 1993 and from 1997 to 1999 . It is important to mention that his younger brother, Shabaz Sharif, has also remained in power in the province of Punjab. In 2013, PML-N, led by Nawaz Sharif, won the election and was elected to the office of Prime Minister for the third time. From the operational point of view, the party also has a distinct family influence; Maryam Nawaz, the daughter of Nawaz Sharif, has emerged as the party's most prominent leader and heir to her father, along with Hamza Shabaz, son of Shabaz Sharif (Shah 2018). In March 2018, Shahbaz Sharif was elected to the chairmanship of PML-N for the second time and was elected to the NA in August of the same year. Shabaz Sharif has a wealth of political resources in Punjab province, because has served as the chief minister of Punjab for three terms, during which time he strengthened his political base.

\subsection{Provincial Political Monopoly Reshaped}

Local factors also play an important role in Pakistan's party politics. Intricate political and business relations and the entangled interests are intertwined in the competition for provincial seats. After the 2018 general election, not only did the vote bank of the PTI increase in Khyber Pakhtunkhwa, but it also secured more votes in Punjab and Sindh, which were prominent vote banks of PML-N and PPP, respectively, changing the seats balance in the provincial assemblies. ${ }^{3}$

\footnotetext{
2 After the death of Zulfiqar Ali Bhutto in 1979, his wife, Nusrat Bhutto, took over as chairman of PPP, and their daughter, Benazir Bhutto, took over in 1984. She was succeeded by her husband, Asif Ali Zardari, after she was killed in a suicide attack in 2007. The party is currently led by Bilawal Bhutto Zardari, the son of Benazir Bhutto and Asif Ali Zardari.

3 There are 371 seats in the Punjab Provincial Assembly, including 297 general seats; 168 seats in the Sindh Provincial Assembly, including 130 general seats; 145 seats in the Khyber Pakhtunkhwa Provincial Assembly, of which 115 are general seats; the total number of seats in the Baluchistan Provincial
} 
Table 2 Provincial seats of three major parties in election 2013 Source: Election Commission of Pakistan 2013

\begin{tabular}{lrrrl}
\hline Party name & Punjab & Sindh & $\begin{array}{l}\text { Khyber Pakh- } \\
\text { tunkhwa }\end{array}$ & Baluchistan \\
\hline PML-N & 214 & 4 & 12 & 8 \\
PPP & 6 & 94 & 3 & 0 \\
PTI & 24 & 2 & 39 & 1 \\
\hline
\end{tabular}

\begin{tabular}{lrrll}
\hline Party name & Punjab & Sindh & $\begin{array}{l}\text { Khyber Pakh- } \\
\text { tunkhwa }\end{array}$ & Baluchistan \\
\hline PML-N & 166 & 0 & 6 & 1 \\
PPP & 7 & 99 & 5 & 0 \\
PTI & 181 & 30 & 85 & 7 \\
\hline
\end{tabular}

Table 3 Provincial seats of three major parties in election 2018 Source: Election Commission of Pakistan 2018

PML-N is dominated by the Sharif family which has been operating in Punjab for 3 decades. The province of Punjab has a dominant position in politics of Pakistan. It has a wide population, a large industrial and agricultural base, and a high economic volume, especially in the federal legislature, which occupies nearly $60 \%$ of the seats. PPP is dominated by the Bhutto family. The three generations of the Bhutto family have ruled in Sindh and established a major electoral base in Sindh. Sindh is located in the southeastern part of Pakistan and south of the Indian Ocean having a prominent coastal city at Karachi.

It can be seen from Table 2 that in the election of the provincial assembly in 2013, PML-N and PPP secured the majority of votes in Punjab and Sindh provinces, respectively. The PTI mainly received support from Khyber Pakhtunkhwa. It is worth mentioning that in 2013, the People's Party won only six seats in Punjab, and the PTI bagged 24 seats in the stronghold of PML-N. According to Malik (2013: 180), the 2013 elections result shows the continuous trend of regionalization in Pakistani politics with different parties controlling different provinces.

Analyzing the 2018 provincial assembly elections shown in Table 3, the PTI has not only consolidated its advantages in Khyber Pakhtunkhwa, but also achieved remarkable results in Punjab and Sindh. Especially in Punjab, the PTI has won 181 seats, while the PML-N electoral strength has been reduced to 166 seats, losing its absolute majority in the Punjab Provincial Assembly. In Sindh, the PTI won 30 seats, and made great progress compared to 2013, while the PML-N did not win a seat in Sindh.

The long-term monopoly over provincial seats shaped by the two prominent political parties has been altered by the third party that is PTI resisting the status quo dynamics. The "anti-status quo" PTI swept the Punjab vote bank that was firmly

Footnote 3 (continued)

Assembly is 65, of which 51 are general seats. Source: http://www.pap.gov.pk; http://www.pabalochistan. gov.pk 
under the influence of PML-N, and also made good headways in Sindh. In this context, the slogan of "change" and "anti-corruption" by PTI has had an enormous impact on the provincial interests of the PPP and the PML-N. The struggle of these three parties at the federal and local level is worth attention because of the election cycle, particularly in Punjab and Karachi. This greater division suggests that the strains facing many of the major parties in the pre-election period did, in fact, have an impact (Cookman 2018).

\section{The Causes of Change in Pakistan's Party Politics}

This section discusses that how PTI managed to create a new space in the political structure of Pakistan which was deeply entrenched by the status quo parties and secure an electoral victory across various political and social dimensions in a relatively short time period. In addition to the personal charisma of Imran Khan (Sandford 2009; Burki 2011; Mishra 2012; Zaidi 2018; Hadid 2018; Ghosh 2018), the authors believe that the ideological appeal, the improvement of organizational level, and the establishment of the mitigation of civil-military relations in Pakistan have played an important role in diversifying the political fabric and endorsed new political changes in party politics. There was dissatisfaction with Pakistan's traditional political parties and PTI's platform and rhetoric reflected it. The public resentment over inflation, corruption, and recurrent power outages coalesced in a populace fed up with the governance failures of the country's major parties: PPP, PML-N, Awami National Party (ANP), and Muttahida Quami Movement (MQM). Young voters in Pakistan were targeted through novel means of outreach such as social media and on novel subjects, such as transparency, accountability, and national pride. The narrative had focused both domestic appeal and an international outlook that influenced voter orientation. This had important impacts on the political system of Pakistan. The participation of people, particularly youth and women, in the political process, expanding the leadership base and extending it to the middle class, anti-status quo politics, and foreign policy orientation are some of the major areas where the impact of novel changes is discussed.

\subsection{PTI's Ideological Appeal}

In Pakistan, the ideology of political parties is the main instrument of legitimacy across both political and social spectrum, and it reflects the unanimous beliefs and common understanding of the members of the party. Since 1996, Imran Khan and PTI have delivered the stark and an uncompromising message that Pakistan's core problems are corruption and the shredding of civilian state institutions by dynastic political elites. Therefore, the PTI-as the only main political party not in powerwas well placed to become a mouthpiece for prevalent grievances. As a result, in 2018, the PTI waged a smart, ruthless, and technically sophisticated election campaign that delivered it the prime ministership (Niaz 2018). 
The idiosyncratic slogans of "change", "anti-elite", and "anti-corruption" characteristic of the PTI ideology maintained a clear distinction between the PTI and other two parties. Furthermore, the PTI claims to stand for "tolerance", call for "national unity", work to "eliminat[e] hatred and religious prejudice." Distinguishing itself from radical parties with Islamic ideologies, it claims a kind of radical and inclusive ideology appealing to Pakistan's expanding middle-class electorate.

At the structural level, PTI believes in corruption-free governance to avoid state erosion and, therefore, calls for a responsible and transparent culture to restore public confidence in the government. Imran Khan calls for a model free from the influence of elites and family interest-oriented politics, thus focusing on achieving political stability through reliable democracy, transparency, and responsible leadership. Previous governments had intentionally stifled accountability institutions to create an environment in which corruption by the ruling elite was concealed rather than aggressively pursued. At the economic and social level, the PTI emphasizes culture of "self-reliance". They believe that continuous government loans from the international community have not helped to develop the economy and improve people's lives hampering the overall growth of the country. Instead, these loans flow into the pockets of corrupt political elites through various projects and various names. PTI advocates the reduction of poverty through economic development and guarantees the right to education of women and children. At the religious level, PTI opposes religious extremism and advocates eradicating the causes of religious extremism from the roots through economic development and social construction. They advocate the focus on addressing the root causes of religious extremism, namely injustice, poverty, unemployment, and illiteracy, and denounce the use of religious dogmas for creating fear and inciting violence.

To get popular support and pursue politico-financial interests, PPP and PML-N have invested in different constituencies creating asymmetries, and have also fostered specific religious and cultural values during the long-term political struggle between the two parties. The two parties have shifted their ideological standpoints about religion and politics in different eras. While the ideology of the PTI advocates inclusiveness, it is highly focused on its pro-people agenda against the clutches of political elites. As a relatively younger political party with no experience ruling at the federal level, it has taken the status quo parties to task while directly referring to the dynastic political traditions and the clientelistism rooted in the depths of their political history. Many young voters in Pakistan preferred to vote for the PTI with its focus on youth, anti-corruption instead of spending a long time waiting for the PPP or PML-N to change their political outlook. As Imran Khan (2011) said, "PTI finally emerged as a tsunami, and it has become the first choice for young people under the age of 30 in Pakistan (about $70 \%$ of the national population)". The ideology of the PTI has a strong appeal to the youth groups in Pakistan. Youth accounts for a large proportion of national population of Pakistan and has made an important contribution in the electoral victory of PTI (Khan 2018a, b). 


\subsection{PTI's Organizational Strength}

In democracies, voting behavior is generally driven by potential to deliver. However, Pakistan is a country where it is driven by patronage and kinship. The relatively balanced hierarchy in organizational structure of PTI distinguishes it from the vertical organizational hierarchy of the PPP and the PML-N. Intra-party elections are a regular feature of the PTI for internal party structure and party nominations at all levels. This unique organizational capacity means that it is undergoing a process of institutionalization, establishing democratic systems in the party. Objectively, it has played a role in rallying consensus and enhancing the mobilization ability of the party.

In March 2012, the PTI announced that it would follow the American-style of nomination process to conduct intra-party elections and introduce local pre-selection meetings at various districts across the country. Aspiring candidates need to participate in debates and win primary elections to be qualified for the party ticket for the provincial or National Assembly. This unprecedentedly large intra-party election was held from October 2012 to March 2013. More than 4 million registered party members participated in the voting. After a long election process, the president of the PTI, the National Committee, and the contestants for federal and provincial assemblies were successfully elected. The PTI became the first political party to hold a nationwide large-scale intra-party election in Pakistan (Rizwan et al. 2016: 83). As a political party with the slogan of 'change' and attracting voters' support, the party election is an important means for PTI to realize this vision. In June 2017, the PTI party launched a large-scale intra-party election campaign again (Wasim 2017). On one hand, through party elections, it is fully "training" the future generation of leaders. On the other hand, through public opinion and propaganda, it established itself as a tough competitor with "family-style" parties.

From the perspective of organizational structure, the PPP and PML-N are "clientelistic parties" similar to one another. In the view of scholars such as Larry Diamond and Richard Gunther (2001: 14), the clientelistic party is a confederation of notables (either traditional or of the newly emerging liberal-professional or economic elite), each with his own geographically, functionally, or personality-based support, organized internally as particularistic factions. Such a party typically has a weak organization and places little or no stress on structure, program, or ideology. There is a vertical network of social relationships within the clientelistic party, that is, higher ranking clientelist seekers use power and resources to benefit the party's candidates, while the latter follow, serve, and respect. In the era of the establishment and expansion of PPP and PML-N, Pakistan's progress was relatively slower, and the country was at a lower level of economic and social development with slow buildup of infrastructure. During their tenure the PPP and PML-N played an active and positive role in promoting democracy: contacting voters, interest aggregation, and social integration. After coming to power, the culture of bribery, corruption, interest exchange, and interest distribution emerged to a greater extent, significantly affecting the development of the country. 


\subsection{The Mitigation of Civil-Military Relations}

Pakistan's party politics has been highly competitive, with both regular elections and dictatorships. However, state functionaries in Pakistan did not evolve into mature political intuitions. The culture of compromise and accepting the political outcomes could also not develop. In the transition from traditional to modern, the parties would not accept the electoral process and results when they lost. The resulting fierce political party struggle has undermined social consensus and distorted the national identity, which ultimately led to the division of the country in 1971. Weak political parties are the major reasons behind the overt and covert rule of dictators in Pakistan (Mahmood 2000: 351).

This paved the way for the military to fill the vacuum, because the political parties lack institutional strength and adoptability. The military would cite the instability created by such situations to justify its actions in the name of ensuring order. The military has played an important role in resisting external threats and maintaining social order, since it enjoys a pivotal position in Pakistan's domestic political situation due its institutional strength and high level of organization. The history of Pakistan's independence also proves that when the relationship between the government and the military is harmonious and stable, Pakistani society will be stable and the economy will develop. Conversely, when the military and the government are in conflict, the army will intervene (Wu 2007: 41). Before the military coup that took place in 1999, Nawaz Sharif as Prime Minister constantly introduced constitutional amendments to expand the power of the Prime Minister, increasing friction with the military. On October 12, 1999, Sharif announced the removal of Musharraf as Chief of Army Staff. Musharraf immediately took countermeasures and staged a coup disbanding Sharif's government. The military regime then lasted for nearly a decade (1999-2008).

The PTI came into being in 1996, surviving difficult times of political tension between civil and military institutions. Imran Khan called this time period "the 14 years of hardest struggle in life (1996-2010)" in his autobiography (Khan 2011: 170).During this period, the PTI did not have a clear or open conflict with the military, but Imran Khan did not accept the offer to become the Prime Minister through undemocratic means, although he is accused, he supported Pervaiz Musharraf in a referendum to become the premier (Tribune 2017).

It surprised observers when its self-proclaimed political "tsunami" drew a crowd 100,000 strong to a rally in Lahore on October 30, 2011 (Behera 2018: 244). Since then, the PTI has enjoyed a sharp rise in popular support, drawing similarly large crowds to rallies around the country (Flamenbaum 2012). The boost helped the party to grow and develop rapidly. This was one of the largest political gatherings in Pakistan's history; even the PTI itself was surprised. Since then, political analysts have begun to take Imran Khan seriously. From 2008 to 2018, Pakistan has achieved two peaceful power transitions under parliamentary democracy. A culture of accepting electoral outcomes developed in this decade unlike during past periods of democracy; the parties did not take radical measures to challenge the democratic system, but the military also exercised restraint and did not directly interfere with the political system. The PTI's security outlook is in line with the country's 
security establishment and there has been considerable stability in civil-military relations since 2008, which had enhanced throughout these years providing favourable grounds to PTI. Therefore, within the country's traditional power structures, a promising space for political restructuring appeared to happen in conversations about the PTI, its viability, and its political competitors.

The literature on political evolution in Pakistan critically discusses the role of the military in politics throughout history (Jahan 1972; Afzal 1976; Ziring 1997; Rizvi 2001). Scholars of the hybrid regime in Pakistan, instead of choosing to focus on electoral process and voters' choices in three consecutive general elections, have credited the PTI's victory to alleged military involvement (Shackle 2019; BR 2019; Imtiaz 2019). According to these scholars, the military establishment intervened in the elections of 2018 and stole the mandate for the PTI. The parties who lost the election alleged that the election was manipulated by the military and that the results were changed at the eleventh hour. According to the insinuations of some top leaders with the incumbent PML-N, the military worked behind the scenes to engineer an electoral outcome resulting in a government helmed by Khan. It's a theory-one could certainly call it a conspiracy theory-embraced by many commentators inside and outside Pakistan (Kugelman 2018).

However, the PTI takes credit of establishing a stable civil military equation achieving excellence in response to such claims. In its report, the Economist Intelligence Unit assumes that the military will continue to provide tacit support to the government (Rehman 2019), partly using its extra-constitutional influence over the country's judicial institutions. When it comes to its foreign and security policies, it will also continue to exert sway over Mr. Khan's administration. As long as the PTI enjoys the support of the military, its junior partners are unlikely to abandon the ruling coalition to join the opposition. From a theoretical point of view, the important aspect is that a political regime is continuing and the process is being strengthened which is unprecedented in the political history of Pakistan considering the occurrences of military coups.

\section{The Impacts of the Novel Change of Party Politics in Pakistan}

Pakistan has shifted from a "two party" to a "three party" system with the introduction of the PTI; the dynastic political tradition has been disturbed; and the concentration of seats in provincial assemblies has been substantially reshuffled. On one hand, with the emergence of new dynamics in the structure of the political parties, the political culture changed. On the other hand, after the PTI came to power by challenging the core bases of status quo parties, it gradually played a larger role in shaping the idea of institutional change.

On the social level, the inclusion of a third political force has brought about two major changes: the participation of youth through social media and an increase in the share of women taking part in politics. Besides structural changes, an important impact was the introduction of young middle-class leadership into mainstream politics. Some women entered the National Assembly for the first time and few even joined the federal cabinet. Murad Saeed, a youngster from the Swat Valley, entered 
into student politics and became the federal minister for communication and postal services. Ali Zaidi was elected to National Assembly from Karachi, becoming minister for Maritime Affairs is another example of young middle-class representation. The PTI phenomenon transformed Pakistan's youth into an accessible and arguably vital voting bloc. The plausible threat of attrition within traditional parties has forced their leadership to consider moving towards somewhat more inclusive decision-making. This has begun to open up more opportunities for vertical movement for all, including the youth (Yusuf 2012).

Additionally, the changes in the dynastic politics brought about by PTI have left the party less constrained by the interests of its leaders' families as it pushes through reforms with an anti-status quo agenda. Though similar to PPP, PML-N, and ANP, PTI is also a highly centralized party which is embodied by Imran Khan's charisma; the difference is that Mr. Khan does not hail from a political family. Unlike the other parties, PTI leadership's political clout was not based on land ownership and industrial wealth. Neither was he prominent in student politics. The Prime Minister Imran Khan's spotless financial reputation set him apart from the incumbent leadership of the other two mainstream political parties. "Khan's anti-incumbent status in politics also gave him an edge vis-à-vis the other party leaders, because he could credibly claim to provide alternative leadership." (Mufti 2015).

Third, the changing composition of provincial assemblies means that the PTI has the ability to push through reforms at a lower level of government than its predecessors. In Punjab and Sindh, PTI changed the monopoly of PPP and PML-N power and quickly emerged as the ruling party. At the local level, PTI worked with many small parties, which had previously worked with PPP and PML-N. To strengthen the federation and to create an administrative balance between Pakistan's federated units, FATA (Federally administered tribal area) has been integrated with KP, efforts for political reconciliation have started in Baluchistan to ensure significant local participation and stake in CPEC and development of Gwadar; to set up a mini civil secretariat in South Punjab, the provincial government has created two new posts of Additional Chief Secretary (ACS) and Additional IG Police (AIGP) to head the police and administrative set-up in the Southern districts. To boost local economy with strategic investments in tourism, minerals, and renewable energy, the PTI government has started providing Gilgit Baltistan with solid opportunities in CPEC by ensuring local participation. However, the governing cooperation between the small parties in provinces and the PTI is new, and the parties are still adjusting to coordinating their interests. PTI is not a dominant force in Punjab, Sindh, and Baluchistan, and its anti-status quo reforms can further undermine its ruling position in the provinces.

With all these developments, we must ask whether this is the same Pakistan or a "New Pakistan," and whether the PTI's rise marks a new political moment, or more of the same. One of the election promises by PTI was revamping foreign policy, though the other political parties claim that the promise was nothing but an electoral gimmick. The novel political changes have casted definite impacts both on domestic structure and foreign policy outlook. New legislation has been introduced, institutional reforms are underway, accountability processes have been triggered, 
new levels of stability in civil military relations achieved, and new middle class and young leaders have emerged.

\subsection{Anti-status Quo Agenda of PTI}

Whether PTI's existing role in Pakistani politics is theorized as continuation of democratic evolution or a new phenomenon, it is important to consider the ways in which the PTI invokes a political status quo. From the federal perspective, PTI has pushed the idea of "change", and has effectively inculcated it into its governance pattern. After the election, Prime Minister Imran Khan spoke to the civil servants of Pakistan, emphasizing the need to materialize the "change" in the system through the bureaucracy. He cited the example of police reforms in Khyber Pakhtunkhwa which led to improved performance in the province. He (PTI 2018a) also mentioned: "Because of the irrationality of the civil service pay system, the bureaucracy is poised with corruption. Because the bureaucracy attracts the best talents, if they get a good reward, they will not be stolen and tempted by financial irregularities". The experience of reforming the police force and improving service delivery at the local level helped, with lessons learned applied in Punjab and at the federal level. In the long run, rebuilding Pakistan's civilian bureaucracy is the only sustainable way to improve public services (Niaz 2018).

Making tough changes requires an extraordinary approach. In September 2018, Imran Khan established the Task Force on Civil Service Reform, chaired by Dr. Ishrat Husain, an institutional reform and austerity measures consultant (TNI 2018). The group consists of 19 people and will be responsible for civil service policy, management, recruitment, training and career planning, drafting the necessary legislation, and designing federal and provincial public service structures. The Education Reform Working Group and the Working Group on the Recovery of Unlawful Hidden Funds Overseas were also established. The former was led by the Federal Minister of Education and Heritage, and was responsible for the reform of the national education system in Pakistan, which was responsible for recovering the illegal hiding of foreign funds by Pakistanis (GEO 2018). These reforms at the federal level will trigger unrest among the original two parties, making political competition more tough and complicated. Moreover, revenue structure reforms have also been proposed and for the first time in history government is attempting to document the whole economic machinery (Dawn 2019). Some stringent measures have been taken in this regard which is been viewed as hostile policy (Haider 2019). PTI appears ready to pay the political cost for imposing reforms, which past governments refused to do. Moreover, a countrywide operation against land encroachments has begun, making a major dent in the PTI's voter base (GVS 2018). Karachi and the federal capital were two strong vote bases for the PTI, but the most rigorous anti-encroachment operations have been conducted in those locales, jeopardizing its vote base. The parties of the left and labor rights activists will definitely use this as a strong electioneering tool.

At the provincial level, especially in Punjab, which accounts for 50\% of Pakistan's population, PTI has also won the position of the largest party in the provincial 
assembly. Punjab used to be the base camp of PML-N and its status in Pakistan's political fabric is very crucial. The PTI won a plurality but not a majority in the Punjab provincial assembly, so it chose to join hands with PML-Q, a rival of PML-N, to set up a government. Imran Khan nominated Sardar Usman Buzdar from PTI to run for the position of Chief Minister of Punjab, and his competitor was Shabaz Sharif, who had governed Punjab for many years. Buzdar triumphed by 186 votes to 159 votes (Yasif 2018). Despite the successful election of Buzdar as the Chief Minister, Shabaz Sharif retained political strength, with considerable numbers in the assembly constituting a tough opposition for the ruling party. In the economic and governance arena, PTI's performance has remained questionable during last year, although it is understood that the PTI government inherited an economic crisis not fixable in a year or perhaps even within a constitutional term.

Its government in Punjab is struggling in its various policies, because it has a disadvantage of less experience in governance of huge province. Compared to its success introducing reforms and improving governance in Khyber Pakhtunkhwa, it will be difficult to achieve major progress in the other three provinces and federal government (Economist 2017). One of the key factors is that Khyber Pakhtunkhwa had never been a strong political base for either the PML-N or the PPP.

In Baluchistan province, the political evolution of parties is very unique. The influence is only casted by ethno-nationalist parties representing Pashtun and Baloch factions. In the past, governments have been formed through coalitions with one of the regional parties, but that pattern changed when a new party, the Baluchistan Awami Party, emerged without any ethno-national orientation. The Baluchistan Awami Party established a provincial government in coalition with the PTI (Dawn 2018). This new coalition trend in the provincial politics corresponds to federalism and sustainable political set-up in Baluchistan. It is also important to note, because Baluchistan has recently become central not only for Pakistani politics but also for external actors.

\subsection{China-Pakistan Engagement Under PTI Government}

Pakistan's new political order is also novel for China, as it engages in both political and economic interactions with Pakistan. Previously, China has dealt with the two parties traditionally dominant in Pakistan's politics. Despite the high degree of competition among the political parties in Pakistan, there is a broad consensus on friendship with China. It is considered as the cornerstone of Pakistan's foreign policy. Both the PPP and the PML-N governments regarded Pakistan-China relations as the most important policy area.

In July 2018, the PTI distinguished itself from the two traditional political parties with speculation about "reversal of China-Pakistan relations," and it raised doubts about the "China-Pakistan Economic Corridor" project (Aamir 2018). This speculation generated concern in policy circles in China. However, this opposition was not directed Pakistan-China, but reflected skepticism about the capacity and financial probity of the PML-N government. In October 2016, Imran Khan told the 
then Chinese Ambassador to Pakistan, Sun Weidong, that "the protests were aimed at launching a survey of the PML-N government, not against China" (Ghumman 2016).

Despite divergences and anxieties over economic issues, China is essential to Pakistan's security requirements. Since his election in July 2018, Imran Khan has stated in various public places that he wants to learn from China on specific practices in anti-corruption, poverty alleviation, and environmental governance (PT 2018). He established a high-power committee for the timely completion of CPEC projects, the China-Pakistan Economic Corridor Authority (Hanif 2019). Before PTI took power, Pakistan was not fully benefiting from CPEC related investments due to insufficient transfer of knowledge and capabilities, limited partnerships with local businesses and its high dependence on imports of goods and services from China.

In November 2018, Imran Khan visited China for the first time as Prime Minister. The Minister of Foreign Affairs of Pakistan, the Minister of Commerce, the Minister of Finance, and the Minister of Railways travelled with him. In addition to meeting with senior officials of the Chinese government, he also held important meetings with Chinese business people and signed 15 memorandums of understanding. These memoranda relate to cooperation agreements in poverty alleviation and strengthening of agriculture, industry, technology and vocational training in Pakistan. At the same time, China continues supporting Pakistan in establishing special economic zones. During his visit to China, Prime Minister Imran Khan also attended the China International Import Expo and delivered a speech as the keynote speaker. In his speech, he emphasized the importance of Pakistan in the "Belt and Road Initiative" and the advantages of the China-Pakistan Economic Corridor, and introduced the important position of Gwadar Port in this initiative (Jamil 2018). Imran Khan's successful visit to China clarified the earlier negative reports on China-Pakistan relations.

The recent visit in October 2019 is testimony to the fact that PTI government takes relationship with China very seriously. In fact, the new changes in Pakistan's party politics will not impact over the China-Pakistan relation due to structural reasons. It is worth noting that under the new changes, changes in provincial political power may bring cooperation risks to specific projects in specific regions, for instance the Orange Line metro project in Lahore is facing management issues particularly after the change of government in Punjab province (Adnan 2019). In Baluchistan alone, none of the three major political parties won a majority.

The projects in the "China-Pakistan Economic Corridor" are distributed in different provinces. Although the PTI has repeatedly expressed its support for the project at the federal level, it is still worth noting whether the specific provinces can mobilize local governance resources. Baluchistan is located in southwestern Pakistan, bordering Afghanistan and Iran, accounting for $40 \%$ of the land mass of the country (Bigham 2006). The Gwadar port at the southernmost tip of the China-Pakistan Economic Corridor is located in Baluchistan. Because Baluchistan accounts for only $5 \%$ of the country's total population, it is lightly represented in the national assembly and has received scant attention. It has difficulty obtaining sufficient resources from the federal government. Social stability, economic development, and security in Baluchistan are grave challenges. After the PTI came to power, it paid a special 
attention to the development of the provinces and it intends to provide transfer payments to both Baluchistan and the erstwhile FATA, now merged into Khyber Pakhtunkhwa.

One of the remarkable economic engagements under PTI government in 2020 was the China-Pakistan Free Trade Agreement-II (CPFTA-II) which became operational from January, eliminating tariffs on 313 tariff lines and giving Pakistan benefits at par with those of ASEAN countries. These 313 items include textiles, engineering items, chemicals, leather, food items, meat, and fisheries, comprising the bulk of Pakistan's exportable products. Phase II would help Pakistan enhance exports to China in coming years through collaboration between the Government and the private sector (Dawn 2020). This year, the two countries began extensive bilateral coordination in the wake of the corona virus pandemic. China contributed and extended the largest amount of assistance to Pakistan in fighting the outbreak. The Ambassador of China to Pakistan, Mr. Yao Jing, reiterated in a recent interview that China--Pakistan cooperation under the BRI and the construction of CPEC will not be hindered by the COVID-19 pandemic (Yao 2020).

The current circumstances provide more opportunity for PTI to develop into a political alternative capable of bolstering the Chinese base in the country, especially given the way in which the party has energized youth participation. Regardless of the party's electoral performance in the years to come, there is a need for making the projects under CPEC politically and economically viable. The PTI's novel vision can transform the political failures of Pakistani politics into an opportunity for it to become more responsive and more accountable.

\section{Conclusion}

Party politics in Pakistan has long been influenced by intrinsic social structures, religion, family, and place. In addition, civil--military relations are key to understanding Pakistani political history. PTI has emerged out of the deeply entrenched social fabric employing novel tactics and creating space by waging resistance to the existing political culture. The transformation indicates dynamism in the political structure of Pakistan, particularly related to party politics under successive transitions of power without any extra institutional hindrance. The challenge to dynastic culture in the party system is a most significant development, indicating the upward trajectory of political evolution; this has combined with an emphasis on anti-corruption and performance, creating pressure for political parties to deliver. The immediate effect has been a strong sense of expectation for economic progress and systemic change, which is facing resistance from domestic political actors.

The peaceful transfer of power between successive governments, the electoral process, and the sustainable multi-party system are omens for the strength of political structure. It would lay the ground for capable leadership, a politically conscious populace and strong state. In such an environment, the question 
of managing external relations particularly with China faced a novelty, since both the sides were new for each other. The core of the China-Pakistan relationship remains intact, but both sides have recalibrated in light of domestic political changes in Pakistan. Some further recalibration will be likely follow, as more understanding develops. It is of pressing importance to strengthen confidence and mutually manage sustainable relations between China and Pakistan.

Acknowledgements We are thankful to Mr. Saul Wilson and Ms. Gulshan Rafique for their valuable inputs and suggestions.

\section{References}

Aamir, Adnan. 2018. Why Pakistan is backing away from Chinese-funded infrastructure projects. South China Morning Post, 19/10/2018. https:/www.scmp.com/comment/insight-opinion/united-states/ article/2169365/why-pakistan-backing-away-chinese-funded. Accessed 28 Aug 2019.

Adnan, Imran. 2019. OLMT project to face further delay. The Express Tribune, 01/04/2019. https://tribu ne.com.pk/story/1941286/1-olmt-project-face-delay/. Accessed 28 Aug 2019.

Ahmed, Naseem. 2010. Military and the Foreign Policy of Pakistan. South Asian Survey 17 (2): 313.

Afzal, M.Rafique. 1976. Political parties in Pakistan, 1947-1958. Islamabad: National Commission on Historical and Cultural Research.

Aziz, K.K. 1976. Party Politics in Pakistan 1947-1958. Lahore: Sang-e-Meel Publications.

BBC. 2008. Musharraf opponents get MPs boost. BBC News, 07/03/2008. http://news.bbc.co.uk/2/hi/ south_asia/7283042.stm. Accessed 25 Aug 2019.

Behera, Ajay Darshan. 2018. Pakistan General Elections 2018: Clear Signs of a Guided Democracy. International Studies 55 (3): 238-252.

Bigham, Alex. 2006. Why Baluchistan Matters. The Guardian, 04/06/2006. https://www.theguardia n.com/commentisfree/2006/jul/04/whybaluchistanmatters. Accessed 28 Aug 2019.

BR. 2019. Civilian institutions and the military. Business Recorder, 15/06/2019. https://fp.brecorder. com/2019/06/20190615486474/. Accessed 1 Mar 2020.

Burki, J.S. 2011. Imran Khan's Political Rise. Institute of South Asian Studies, 27/12/2011. https://www. files.ethz.ch/isn/135577/ISAS_Insights_149_-_Imran_Khans_Political_Rise_27122011175801.pdf. Accessed 12 Aug 2019.

Chaudhary, S.N. 2013. How did they do? Grading the PPP. Foreign Policy, 28/03/2013. https://foreignpol icy.com/2013/03/28/how-did-they-do-grading-the-ppp/. Accessed 23 Sept 2019.

Cookman, Colin. 2010. The 18th Amendment and Pakistan's Political Transitions. Center for American Progress, 19/04/2010. https://www.americanprogress.org/issues/security/news/2010/04/19/7587/ the-18th-amendment-and-pakistans-political-transitions/. Accessed 25 Aug 2019.

Cookman, Colin. 2018. A Tilted Playing Field: What Pakistan's Electoral Shifts Could Mean for Imran Khan's Government. Texas National Security Review, 08/08/2018. https://warontherocks. com/2018/08/a-tilted-playing-field-what-pakistans-electoral-shifts-could-mean-for-imran-khans -government/. Accessed 20 Aug 2019.

Dawn. 2018. Jam Mir Kamal gets elected BAP chief, urges unity for Baluchistan's rights. The Dawn, 17/05/2018. https://www.dawn.com/news/1408175/jam-mir-kamal-gets-elected-bap-chief-urges -unity-for-balochistans-rights. Accessed 1 Mar 2020.

Dawn. 2019. Documenting the economy. The Dawn, 12/05/2019. https://www.dawn.com/news/1481775. Accessed 1 Mar 2020.

Dawn. 2020. New FTA with China is a marked improvement. The Dawn, 26/01/2020. https://www.dawn. com/news/1530592. Accessed 30 May 2020.

Economist. 2017. Imran Khan's Party Improves Services in Pakistan's Wildest Province. The Economist, 08/07/2017. https://www.economist.com/asia/2017/06/08/imran-khans-party-improves-services-inpakistans-wildest-province. Accessed 25 Sep 2019.

Flamenbaum, Stephanie. 2012. The PTI and Pakistan's Changing Political Landscape. United States Institute of Peace, 24/05/2012. https://www.usip.org/sites/default/files/resources/PB-127.pdf. Accessed 22 Aug 2019. 
GEO. 2018. PM forms task force for civil service reforms. GEO News, 06/09/2018. https://www.geo.tv/ latest/210140-pm-forms-task-force-for-civil-service-reforms. Accessed 16 Sept 2019.

Ghosh, Avijit. 2018. Imran Khan: From top cricketer to winning politician. The Times of India, 27/07/2018. https://timesofindia.indiatimes.com/world/pakistan/imran-khan-from-top-cricketer-towinning-politician/articleshow/65155894.cms. Accessed 7 Sept 2019.

Ghumman, Khawar. 2016. Protests not against CPEC, PTI chief assures Chinese envoy. The Dawn,19/10/2016. https://www.dawn.com/news/1290877. Accessed 22 Sept 2019.

Gunther, Richard, and Larry Diamond. 2001. Types and Functions of Parties. In Political Parties and Democracy, ed. Larry Diamond and Richard Gunther, 14. Baltimore: The Johns Hopkins University Press.

GVS. 2018. Government's anti-encroachment drive may backfire in upcoming by-polls?. Global Village Space, 12/09/2018. https://www.globalvillagespace.com/governments-anti-encroachmentdrive-may-backfire-in-upcoming-by-polls/. Accessed 2 Mar 2020.

Hadid, Diaa. 2018. Imran Khan: From Swaggering Cricketer to Populist Prime Minister. National Public Radio,29/07/2018. https://www.npr.org/2018/07/29/633544287/imran-khan-from-crick eter-to-prime-minister. Accessed 7 Sep 2019.

Haider, Murtaza. 2019. Which political party has been the best for Pakistan's economy? Trade stats reveal all. The Dawn, 16/11/2019. https://www.dawn.com/news/1482443. Accessed 1 Mar 2020.

Hanif, Haseeb. 2019. CPEC authority being established. The Express Tribune, 14/07/2019. https://tribu ne.com.pk/story/2012875/1-cpec-authorityestablished-says-bakhtiar. Accessed 1 Mar 2020.

Hussain, Asif. 1979. Elite Politics in an Ideological State: The Case of Pakistan. England: Wm Dawson \& Sons Ltd.

Hussain, Ejaz. 2013. Military Agency. Samskriti: Politics and the State in Pakistan.

Imtiaz, Rai Mansoor. 2019. The role of the military and an unrecognized political transformation in the 2018 general election in Pakistan. The Asia Dialogue, 14/11/2019. https://theasiadialogue .com/2019/11/14/the-role-of-the-military-and-an-unrecognised-political-transformation-in-the2018-general-election-in-pakistan/. Accessed 1 Mar 2020.

Jahan, Rounaq. 1972. Pakistan: Failure in National Integration. New York: Columbia University Press.

Jamil, Sidra Tariq. 2018. PM Khan's Successful Visit to China: Deepening the Relationship and Strengthening Ties. Pakistan Tehreek-e-Insaf, 08/11/2018. http://www.insaf.pk/public/insafpk/ blog/khans-successful-visit-china-relationship-strengthening-ties. Accessed 23 Sep 2019.

Khan, Abbas Amjad. 2018. Nature and Contours of Party Politics in Pakistan. Journal of the Punjab University Historical Society, 31(2). http://pu.edu.pk/images/journal/HistoryPStudies/PDF_Files /03_v31_2_july2018.pdf. Accessed 16 Aug 2019.

Khan, Imran. 2011. Pakistan: A Personal History. London: Bantam Press.

Khan, Sahar. 2018. Pakistan's Youth: An Untapped Resource by Pakistan's Political Parties. Cato Institute, 24/07/2018. https://www.cato.org/blog/pakistans-youth-untapped-resource-pakistanspolitical-parties. Accessed 16 Aug 2019.

Kugelman, Michael. 2018. Is Imran Khan the Pakistani military's 'favouriteson'?. Al Jazeera, 23/07/2018. https://www.aljazeera.com/indepth/opinion/imran-khan-pakistani-military-favou rite-son-180723044709061.html. Accessed 1 Mar 2020.

Mahmood, Safdar. 2000. Pakistan Political Roots and Development 1947-1999. Karachi: Oxford University Press.

Malik, Anas. 2011. Political Survival in Pakistan. Oxon: Routledge.

Malik, Anas. 2013. Pakistan in 2013: A milestone in democratic transition. Asian Survey 54 (1): 180.

Mishra, Pankaj. 2012. Imran Khan Must Be Doing Something Right. The New York Times Magazine, 16/08/2012. https://www.nytimes.com/2012/08/19/magazine/pakistans-imran-khan-must-be-doing -something-right.html. Accessed 12 Aug 2019.

Mufti, Mariam. 2015. Pakistan Tehreek-e-Insaaf: A New Phenomenon or A Continuation of the Political Status Quo?. Network of Research in International Affairs. https://www.noria-research.com/ app/uploads/2016/10/Noria-MUFTI-Pakistan-VE-PDF.pdf. Accessed 10 Aug 2019.

NAP. 2019. Party-Wise Graph. National Assembly of Pakistan, 05/08/2019. http://www.na.gov.pk/en/ party-stats.php. Accessed 5 Aug 2019.

Niaz, Ihan. 2018. The politics of redemption and the rise of Imran Khan. East Asia Forum, 27/08/2018. https://www.eastasiaforum.org/2018/08/27/the-politics-of-redemption-and-the-riseof-imran-khan/. Accessed 25 Aug 2019. 
PRI. 2013. Historic election marks transition in Pakistan. Public Radio International, 14/05/2013. https://www.pri.org/stories/2013-05-14/historic-election-marks-transition-pakistan. Accessed 6 Sept 2019.

PT. 2018. China to support Pakistan in fighting corruption. Pakistan Today, 15/10/2018. https://www. pakistantoday.com.pk/2018/10/15/china-to-support-pakistan-in-fighting-corruption/. Accessed 24 Sep 2019.

PTI. 2018a. Prime Minister Imran Khan Speaking to The Government Employees. Pakistan Tehreeke-Insaf, 14/09/2018. http://www.insaf.pk/public/insafpk/news/prime-minister-imran-khan-speak ing-government-employees-sep-14th-2018. Accessed 15 Sep 2019.

Rafiq, Arif. 2012. The Imran Khan Phenomenon. Foreign Policy, 12/01/2012. https://foreignpolicy. com/2012/01/12/the-imran-khan-phenomenon/. Accessed 12 Aug 2019.

Rehman, Atika. 2019. Military will continue to shape security, foreign policy: report. The Dawn, 08/11/2019. https://www.dawn.com/news/1515569/military-will-continue-to-shape-securityforeign-policy-report. Accessed 1 Mar 2020.

Rizvi, Hassan Askari. 2001. The Military and Politics in Pakistan 1947-1997. Lahore: Sang-e-Meel Publishers.

Rizwan, Muhammad, Manzoor Ahmad, and Muhammad Bilal. 2016. Intra-Party Democracy in Pakistan Tehrik-e-Insaf. Global Regional Review 1 (1): 75-84.

Saeed, Khalid. 1966. 1965-An Epoch Making Year in Pakistan-General Elections and War with India. Asian Survey 6 (2): 76-85.

Sandford, Christopher. 2009. Imran Khan: The Cricketer, the Celebrity, the Politician. HarperCollins.

Shackle, Samira. 2019. Imran Khan has won over Pakistan. But real power still lies with the army. The Guardian, 27/07/2018. https:/www.theguardian.com/commentisfree/2018/jul/27/imran-khanwon-pakistan-power-army-military-election. Accessed 1 Mar 2020.

Shah, Aamir. 2018. Is Pakistan's Sharif Dynasty Crumbling?. Arab News, 24/04/2019. https://www. arabnews.pk/node/1290246/world. Accessed 22 Sep 2019.

Shah, Aqil. 2013. Nawaz Sharif, 3.0 His Third Time in Office Could Be the Charm. Foreign Affairs, 13/05/2013. https://www.foreignaffairs.com/articles/pakistan/2013-05-13/nawaz-sharif-30. Accessed 25 Sep 2019.

Tahir, Madiha. 2012. I'll be your mirror. The Caravan 4 (1): 41.

Taseer, Salmaan. 1979. Bhutto: A Political Biography. London: Ithaca Press.

TNI. 2018. Bureaucratic reforms. The News International, 08/10/2018. https://www.thenews.com.pk/ print/377930-bureaucratic-reforms. Accessed 16 Sep 2019.

Tribune. 2013. Simple majority? Many independent candidates join PML-N. The Express Tribune, 14/05/2013. https://tribune.com.pk/story/549100/raiwind-meetings-pml-n-begins-talks-withindependent-candidates/. Accessed 6 Sep 2019.

Tribune. 2017. Imran backed Musharraf in hope of becoming PM. The Express Tribune, 04/02/2017. https://tribune.com.pk/story/1316630/workers-convention-imran-backed-musharraf-hope-becom ing-pm/. Accessed 25 Sep 2019.

Tupsy, Cassam. 2018. Imran khan, the emerging charismatic leader of Pakistan. Sunday Times, 07/08/2018. https://www.sundaytimesmauritius.com/imran-khan-the-emerging-charismati c-leader-of-pakistan/. Accessed 13 Aug 2019.

Wasim, Amir. 2017. Overdue PTI intra-party elections on June 11. The Dawn, 14/05/2017. https:// www.dawn.com/news/1333039. Accessed 9 Sep 2019.

Wu, Yongnian. 2007. The Military Regime and Democracy in Pakistan. World Economics and Politics 11: 41.

Yao, jing. 2020. Ambassador Yao Jing: Epidemic won't Hinder China-Pakistan Cooperation on Belt and Road Initiative. Embassy of the People's Republic of China in the Islamic Republic of Pakistan, 04/02/2020. http://pk.chineseembassy.org/eng/zbgx/t1748068.htm. Accessed 30 May 2020.

Yasif, Rana. 2018. PTI's Usman Buzdar becomes new Punjab chief minister. The Express Tribune, 19/08/2018. https://tribune.com.pk/story/1784399/1-punjab-assembly-pick-20th-chief-minister/. Accessed 16 Sept 2019.

Yusuf, Huma. 2011. The Imran Khan Phenomenon. Foreign Policy, 31/10/2011. https://foreignpolicy. com/2011/10/31/explaining-the-rise-of-imran-khan/. Accessed 12 Aug 2019.

Yusuf, Moeed. 2012. PTI impact on politics. The Dawn, 23/01/2012. https://www.dawn.com/ news/690173/pti-impact-on-politics. Accessed 1 Mar 2020.

Yousaf, Salman. 2016. Political marketing in Pakistan: exaggerated promises, delusive claims, marketable development projects and change advocacy. Journal of Public Affairs 16 (2): 140-155. 
Zaidi, S. Akbar. 2018. Imran Khan and His Naya Pakistan, Economic \& Political Weekly, August 4, 2018.

Ziring, Lawrence. 1997. Pakistan in the Twentieth Century: A Political History. Karachi: Oxford University Press.

Xiang Wu is a Ph.D. candidate in the School of International Relations and Public Affairs, Fudan University. His research focuses on party politics of Pakistan and civil-military relations in South Asia.

Salman Ali is a Ph.D. candidate in the School of International Relations and Public Affairs, Fudan University, and on leave from School of Politics and International Relations, Quaid-i-Azam University as lecturer. His research focus is on Politics of Pakistan, South Asia, and rise of China. 